INDONESIA ACCOUNTING JOURNAL

VOLUME 2, NUMBER 2, YEAR 2020

${ }^{1}$ Corresponding author

Program Studi Akuntansi

Fakultas Ekonomi

Universitas Nuku

Jl. Sultan Mansur

Tidore, Indonesia, 97813

E-mail: madj.farid@gmail.com

${ }^{2}$ Program Studi Manajemen

Fakultas Ekonomi

Universitas Nuku

Jl. Sultan Mansur

Tidore, Indonesia, 97813

Article info:

Received 22 October 2020

Accepted 23 October 2020

Available online 23 October 2020

Keywords: management; BUMDes; village potential

JEL Classification: H11, H61, H72, H83

DOI: http://doi.org/10.32400/iaj.31055

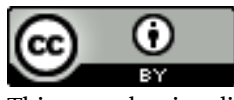

This work is licensed under a

Creative

Commons

Attribution

4.0

International License.

\section{Analisis kinerja Badan Usaha Milik Desa dalam pengelolaan anggaran untuk meningkatkan pengolahan potensi desa di Desa AkedotilouC}

\author{
Farid Madjodjo \\ Fadli Dahlan ${ }^{2}$
}

\begin{abstract}
This study uses qualitative approach with purpose to determine: (1) the performance of BUMDes in budget management; and (2) the performance of the "Karivela" BUMDes in managing village potential in Akidotilou Village of Oba Tengah District in Tidore Kepulauan City of North Maluku Province. Data collection techniques through observation, interviews, documentation, and literature study. Data analysis procedures include data collection, data reduction, data presentation, and drawing conclusions. The results show that budget management by BUMDes "Karivela" which should be accountable for budget management to the Village Government of Akedotilou Oba Tengah Subdistrict Tidore Islands City has not been carried out by BUMDes "Karivela" officials. So that every BUMDes "Karivela" budget is known to lack transparency, both in management and accountability. Meanwhile, in the management of village potential in the Village managed by BUMDes "Karivela" there is still no improvement in the existing business units. this is because the management of the BUMDes "Karivela" does not have the ability to manage the village potential in Akedotilou village and the lack of human resources who manage the village potential.
\end{abstract}

\section{Pendahuluan}

Badan Usaha Milik Desa (BUMDes) adalah lembaga usaha desa yang dikelola oleh masyarakat dan pemerintah desa dalam upaya memperkuat perekonomian desa dan dibentuk berdasarkan kebutuhan dan potensi desa (Swandari et al., 2017). BUMDes bertujuan untuk meningkatkan pendapatan dan ekonomi desa sesuai dengan kebutuhan dan potensi yang dimiliki desa. Modal BUMDes menggunakan dana desa dari pemerintah pusat yang diberikan untuk desa. Dengan bantuan modal dari pemerintah pusat, BUMDes bisa mengkapitalisasi potensi-potensi yang ada di desa untuk mensejahterakan masyarakat. Dalam menjalankan suatu usaha baik sektor swasta maupun sektor publik dituntut untuk melakukan pengelolaan anggaran secara akuntabel dan transparan. Akuntabilitas adalah pertanggungjawaban kepada publik atas setiap aktivitas yang dilakukan (Mardiasmo, 2009:18). Sedangkan transparansi berarti keterbukaan pemerintah dalam memberikan informasi yang terkait dengan aktivitas pengelolaan sumber daya publik kepada pihak-pihak yang membutuhkan informasi (Hehanussa, 2015).

Berdasarkan pengamatan awal di lapangan, Desa Akedotilou memiliki Badan Usaha Milik Desa (BUMDes) yang diberi nama BUMDes Karivela, yang didirikan sejak tahun 2017, dengan 3 (tiga) anggota pengurus. Pada tahun 2017, BUMDes ini telah memperoleh anggaran dari penyertaan modal pemerintah desa sebesar Rp.400 juta yang bersumber dari dana desa tahun anggaran 2017. Pada tahun 2018 dan tahun 2019, BUMDes Karivela belum mendapatkan penyertaan modal dari 
pemerintah desa, hal ini dikarenakan anggaran tahun 2017 masih tersisa di kas BUMDes sebesar Rp. 200 juta, yang belum dimanfaatkan secara maksimal oleh BUMDes untuk membiayai program kerja yang dijalankan BUMDes demi kesejahteraan masyarakat desa. Salah satu kegiatan yang dijalankan BUMDes Karivela ini adalah membuka usaha penjualan pupuk organik dan obat-obatan pertanian, untuk kebutuhan pertanian di desa sendiri maupun di desa-desa yang ada di sekitarnya, tetapi tidak dijalankan secara maksimal oleh pengurus BUMDes. BUMDes Karivela ini juga, belum mengelola potensi desa yang ada di Desa Akedotilou, selain itu anggaran yang dikelola BUMDes belum melakukan pelaporan kepada pemerintah desa, hal ini disebabkan sumber daya manusia yang mengelola BUMDes masih sangat minim. Dengan demikian, dari kinerja BUMDes Karivela sampai saat ini diduga masih belum menjawab kebutuhan masyarakat, khususnya dari segi akuntabilitas maupun transparansi.

Berdasarkan permasalahan tersebut, penelitian ini bertujuan untuk mengkaji lebih jauh tentang kinerja BUMDes Karivela dan pengelolaan anggaran BUMDes Karivela dalam mengelola potensi desa. Secara khusus, tujuan dari penelitian ini adalah untuk mengetahui: (1) kinerja Badan Usaha Milik Desa Karivela dalam mengelola potensi desa di Desa Akedotilou; dan (2) pengelolaan anggaran Badan Usaha Milik Desa Karivela dalam mengelola potensi desa di Desa Akedotilou.

\section{Tinjauan pustaka}

\section{Badan Usaha Milik Desa (BUMDes)}

BUMDes adalah lembaga usaha desa yang dikelola oleh masyarakat dan pemerintahan desa dalam upaya memperkuat perekonomian desa dan dibentuk berdasarkan kebutuhan dan potensi desa. Dalam Undang-Undang No. 32 tahun 2004 tentang Pemerintahan Daerah pada Pasal 213 ayat 1 disebutkan bahwa "Desa dapat mendirikan badan usaha milik desa sesuai dengan kebutuhan dan potensi desa". Sebagai salah satu lembaga ekonomi yang beroperasi di pedesaan,
BUMDes harus memiliki perbedaan dengan lembaga ekonomi pada umumnya, dimana hal ini dimaksudkan agar keberadaan dan kinerja BUMDes mampu memberikan kontribusi yang signifikan terhadap peningkatan kesejahteraan warga desa. Selain itu, BUMDes juga mencegah berkembangnya sistem usaha kapitalistis di pedesaan yang dapat mengakibatkan terganggunya nilai-nilai kehidupan bermasyarakat. Badan Usaha Milik Desa, yang selanjutnya disebut BUMDes dalah usaha desa yang dibentuk/didirikan oleh pemerintah desa yang kepemilikan modal dan pengelolaannya dilakukan oleh pemerintah desa dan masyarakat. Menurut Permendagri No. 39 tahun 2010, pasal 1 ayat 6, BUMDes sebagai suatu lembaga ekonomi modal usahanya dibangun atas inisiatif masyarakat dan menganut asas mandiri. Hal ini berarti pemenuhan modal usaha BUMDes harus bersumber dari masyarakat. Meskipun demikian, tidak menutup kemungkinan BUMDes dapat mengajukan pinjaman modal kepada pihak luar, bahkan melalui pihak ketiga. Penjelasan ini sangat penting untuk mempersiapkan pendirian BUMDes, karena implikasinya akan bersentuhan dengan pengaturannya dalam Peraturan Daerah (Perda) maupun Peraturan Desa (Perdes). Menurut (Nugrahaningsih et al. 2016), terdapat 7 (tujuh) ciri utama yang membedakan BUMDes dengan lembaga ekonomi komersial pada umumnya yaitu:

1. Badan usaha ini dimiliki oleh desa dan dikelola secara bersama;

2. Modal usaha bersumber dari desa (51\%) dan dari masyarakat (49\%) melalui penyertaan modal (saham atau andil);

3. Operasionalisasinya menggunakan falsafah bisnis yang berakar dari budaya lokal (local wisdom);

4. Bidang usaha yang dijalankan didasarkan pada potensi dan hasil informasi pasar;

5. Keuntungan yang diperoleh ditujukan untuk meningkatkan kesejahteraan anggota (penyerta modal) dan masyarakat melalui kebijakan desa (village policy); 
6. Difasilitasi oleh Pemerintah pusat, Pemerintah Provinsi, Pemerintah Kabupaten, dan Pemerintah Desa;

7. Pelaksanaan operasionalisasi dikontrol secara bersama (Pemerintah Desa, Badan Permusyawaratan Desa, dan anggota).

\section{Tujuan perencanaan Badan Usaha Milik Desa (BUMDes)}

Pendirian dan pengelolaan (BUMDes) adalah merupakan perwujudan dari pengelolaan ekonomi produktif desa yang dilakukan secara kooperatif, partisipatif, emansipatif, transparansi, akuntabel, dan berkelanjutan. Oleh karena itu, perlu upaya serius untuk menjadikan pengelolaan badan usaha tersebut dapat berjalan secara efektif, efisien, profesional dan mandiri. Pencapaian pengelolaan ekonomi produktif untuk mencapai tujuan BUMDes dilakukan dengan cara memenuhi kebutuhan (produktif dan konsumtif) masyarakat melalui pelayanan distribusi barang dan jasa yang dikelola masyarakat dan Pemerintah Desa. Pendirian BUMDes adalah merupakan perwujudan dari pengelolaan ekonomi produktif desa yang dilakukan secara kooperatif, partisipasif, emansipatif, transparansi, akuntabel, berkelanjutan (Sasauw et al., 2018). Pemenuhan kebutuhan ini diupayakan tidak memberatkan masyarakat, mengingat BUMDes akan menjadi usaha desa yang paling dominan dalam menggerakkan ekonomi desa. Menurut Peraturan Menteri Desa, Pembangunan Daerah Tertinggal, dan Transmigrasi Nomor 4 Pasal 3 tahun 2015 tentang Pendirian, Pengurusan dan Pengelolaan, dan Pembubaran Badan Usaha Milik Desa, bahwa pendirian BUMDes bertujuan untuk: (1) meningkatkan perekonomian desa; (2) mengoptimalkan aset desa agar bermanfaat untuk kesejahteraan desa; (3) meningkatkan usaha masyarakat dalam pengelolaan potensi ekonomi desa; (4) mengembangkan rencana kerja sama usaha antar desa dan/atau dengan pihak ketiga; (5) menciptakan peluang dan jaringan pasar yang mendukung kebutuhan; (6) layanan umum warga; (7) membuka lapangan kerja; (8) meningkatkan kesejahteraan masyarakat melalui perbaikan pelayanan umum, pertumbuhan dan pemerataan ekonomi desa; dan (9) meningkatkan pendapatan masyarakat desa dan pendapatan asli desa.

BUMDes sebagai badan usaha yang dibangun atas inisiatif masyarakat dan menganut asas mandiri, harus mengutamakan perolehan modalnya yang berasal dari masyarakat dan Pemerintah Desa. Meskipun demikian, terdapat kecenderungan BUMDes dapat memperoleh modal dari pihak luar, seperti dari Pemerintah Kabupaten atau pihak lain, bahkan dapat pula melakukan pinjaman kepada pihak ketiga, sesuai peraturan perundang-undangan. Pengaturan lebih lanjut mengenai BUMDes tentunya akan diatur melalui Peraturan Daerah (Perda).

\section{Pengelolaan anggaran Badan Usaha Milik Desa (BUMDes)}

Permendagri Nomor 113 Tahun 2014, pasal 1 ayat 5 dan 6 menyebutkan bahwa keuangan desa adalah semua hak dan kewajiban desa yang dapat dinilai dengan uang serta segala sesuatu berupa uang dan barang yang berhubungan dengan pelaksanaan hak dan kewajiban desa. Pengelolaan keuangan desa adalah keseluruhan kegiatan yang meliputi perencanaan, pelaksanaan, pelaporan, dan pertanggungjawaban keuangan desa. BUMDes diharapkan dapat mendukung munculnya kembali demokrasi sosial di desa melalui peningkatan kapasitas masyarakat desa tentang pengelolaan BUMDes secara berkelanjutan, dan partisipasi masyarakat desa terhadap BUMDes juga tidak lagi berkurang. Pemerintah desa juga mampu berpola kreatif dan inovatif dalam mendominasi kegiatan ekonomi desa melalui kepemilikan BUMDes sehingga dapat membangun perekonomian daerah yang dibutuhkan untuk menciptakan lapangan pekerjaan baru, menghasilkan barang dan jasa substitusi daerah, meningkatkan perdagangan antar-pemerintah daerah dan memberikan layanan yang optimal bagi konsumen. BUMDes dapat berdiri dengan tujuan sebagai agen pembangunan daerah 
dan menjadi pendorong terciptanya sektor korporasi di pedesaan tetapi dengan biaya produksi dan pengelolaan tidak terlalu tinggi (Irawati dan Martanti, 2017). Tujuan dan sasaran BUMDes dapat tercapai jika BUMDes dikelola secara terarah dan profesional (Agunggunanto et al., 2016). Dalam hal untuk mempertanggungjawabkan pengelolaan anggaran, BUMDes juga membutuhkan laporan keuangan yang bertujuan untuk menyajikan informasi mengenai posisi keuangan, realisasi anggaran, arus kas, dan kinerja keuangan suatu entitas pelaporan yang bermanfaat bagi para pengguna dalam membuat dan mengevaluasi keputusan mengenai alokasi sumber daya. Tujuan pelaporan keuangan pemerintah adalah menyajikan informasi yang berguna untuk pengambilan keputusan untuk menunjukkan akuntabilitas entitas pelaporan sumber daya yang dipercaya kepadanya (Irawati dan Martanti, 2017).

Dalam organisasi sektor publik terdapat dua jenis pelaporan, yaitu pelaporan kinerja dan pelaporan keuangan. Pelaporan kinerja merupakan refleksi kewajiban untuk mempresentasikan dan melaporkan kinerja seluruh aktivitas serta sumber daya yang harus dipertanggunggjawabkan, pelaporan kinerja ini merupakan wujud dari proses akuntabilitas. Pelaporan keuangan merupakan cerminan dari posisi keuangan serta seluruh transaksi yang telah dilakukan oleh suatu entitas dalam suatu periode tertentu, hasil dari pelaporan ini berupa laporan keuangan (Irawati dan Martanti, 2017). Laporan keuangan adalah suatu penyajian terstruktur dari posisi keuangan dan kinerja keuangan suatu entitas (Risal et al., 2020). Pengelolaan dana yang transparan akan membuat masyarakat dan pemerintah dapat mengetahui untuk apa saja dana pemerintah digunakan. Prinsip transparan dapat diukur melalui indikator, yaitu: (1) mekanisme menjamin sistem keterbukaan dan standarisasi dari semua proses pelayanan publik; (2) mekanisme yang memfasilitasi pertanyaan-pertanyaan publik tentang berbagai kebijakan dan pelayanan publik maupun proses di dalam sektor publik; dan (3) mekanisme memfasilitasi pelaporan maupun penyebaran informasi dan penyimpanan tindakan aparat publik di dalam kegiatan melayani. BUMDes sebagai lembaga keuangan desa yang menjalankan bisnis keuangan (financial business) yang memenuhi kebutuhan usaha-usaha skala mikro yang dijalankan oleh pelaku usaha ekonomi desa, BUMDes wajib membuat laporan keuangan seluruh unit usaha BUMDes secara akuntabel dan transparan yang dilakukan setiap bulannya (Sukarini et al., 2018). Lebih lanjut, BUMDes juga wajib memberikan laporan perkembangan unitunit usaha BUMDes kepada masyarakat desa melalui musyawarah desa yang sekurang-kurangnya 2 (dua) kali dalam 1 (satu) tahun.

\section{Metode penelitian}

\section{Jenis dan sumber data}

Jenis data dalam penelitian ini adalah data kualitatif, dimana data kualitatif diperoleh dari hasil pengamatan dan wawancara pada pengurus BUMDes Karivela dan Pemerintah Desa Akedotilou Kecamatan Oba Tengah Kota Tidore Kepulauan Provinsi Maluku Utara yang menjadi objek dalam penelitian ini. Sumber data yang digunakan adalah data primer dan data sekunder. Data primer diperoleh dari hasil wawancara langsung kepada pengurus BUMDes dan Pemerintah Desa terkait dengan kinerja BUMDes Karivela dan Pengelolaan Anggaran BUMDes Karivela yang menjadi objek penelitian. Sedangkan data sekunder diperoleh untuk mendukung penelitian seperti referensi-referensi yang terkait dengan penelitian ini.

\section{Sampel dan teknik pengambilan sampel}

Teknik pengambilan sampel dalam penelitian ini menggunakan teknik purposive sampling atau sampel bertujuan. Purposive sampling adalah teknik pengambilan sampel sumber data dengan pertimbangan tertentu (Sugiyono, 2016:124). Sampel penelitian ini adalah pengurus BUMDes Karivela (Ketua, Bendahara, dan Sekretaris) dan pemerintah Desa Akedotilou (Kepala Desa, Bendahara Desa, dan Sekretaris Desa), sehingga sampel yang diambil sebagai informan penelitian 
adalah sebanyak 6 (enam) orang. Sampel diambil dengan pertimbangan tertentu karena dianggap lebih banyak mengetahui informasi terkait dengan permasalahan penelitian.

\section{Teknik pengumpulan data}

Teknik pengumpulan data yang digunakan pada penelitian ini adalah:

1. Observasi, metode pengumpulan data dengan cara pengamatan langsung pada objek yang diteliti.

2. Wawancara, metode untuk mendapatkan data dengan cara tanya jawab langsung dengan pengurus BUMDes, apatur pemerintah desa tentang kinerja BUMDes, pengelolaan anggaran serta pengolahan potensi desa untuk menunjang penelitian ini.

3. Dokumentasi, dilakukan dengan cara mengumpulkan data melalui dokumen baik yang berbentuk tulisan, gambar atau karya-karya monumental seseorang, dan menyalin, melihat, serta mengevaluasi laporan dan dokumen-dokumen yang terkait dengan objek penelitian.

4. Studi literatur, metode pengumpulan data dengan cara melakukan peninjauan pustaka dari berbagai literatur dan bukubuku yang terkait dengan teori-teori yang relevan dengan penelitian ini.

\section{Metode analisis}

Metode analisis data yang digunakan pada penelitian ini disesuaikan dengan jenis penelitian. Dengan demikian metode analisis yang digunakan meliputi:

1. Reduksi data. Reduksi data bukanlah suatu hal yang terpisah dari analisis. Reduksi data diartikan sebagai proses pemilihan, pemusatan perhatian pada penyederhanaan, pengabstraksian, dan transformasi data kasar yang muncul dari catatan-catatan tertulis di lapangan.

2. Penyajian data. Penyajian data yang sering digunakan pada data kualitatif adalah bentuk naratif. Penyajian-penyajian data berupa sekumpulan informasi yang tersusun secara sistematis dan mudah dipahami.
3. Penarikan kesimpulan. Penarikan kesimpulan merupakan tahap akhir dalam analisis data yang dilakukan melihat hasil reduksi data tetap mengaju pada rumusan masalah secara tujuan yang hendak dicapai. Data yang telah disusun dibandingkan antara satu dengan yang lain untuk ditarik kesimpulan sebagai jawaban dari permasalahan yang ada.

\section{Hasil penelitian dan pembahasan \\ Gambaran umum BUMDes "Karivela"}

BUMDes "Karivela" merupakan salah satu badan usaha yang dikelola oleh masyarakat Desa Akedotilou Kecamatan Oba Tengah Kota Tidore Kepulauan. Pengurus BUMDes "Karivela" meliputi Ketua, Sekretaris, dan Bendahara. BUMDes "Karivela" didirikan sejak tahun 2017 berdasarkan Surat Keputusan kepala Desa Akedotiou, yang pada saat itu belum diatur secara khusus dalam Peraturan Desa (Perdes) tentang Badan Usaha Milik Desa (BUMDes). Surat Keputusan Kepala Desa tentang pendirian BUMDes "Karivela" mengacu pada Undang-Undang Nomor 6 tahun 2014 tentang Desa yang menyebutkan bahwa Badan Usaha Milik Desa, yang selanjutnya disebut BUM Desa, adalah badan usaha yang seluruh atau sebagian besarnya modalnya dimiliki oleh desa melalui kekayaan desa yang dipisahkan guna mengelola aset, jasa pelayanan, dan usaha lainnya untuk sebesar-besarnya kesejahteraan masyarakat Desa. Pokokpokok pengelolaan BUMDes "Karivela" berdasarkan pada Anggaran Dasar Rumah Tangga BUMDes sebagai pedoman dalam pengelolaannya. Jenis-jenis usaha yang dilakukan oleh BUMDes "Karivela", yaitu:

1. Penyediaan obat-obatan pertanian. Penyediaan obat-obatan pertanian yang dilakukan BUMDes Karivela merupakan salah satu usaha untuk menggali sumber potensi desa yang ada di wilayah Desa Akedotilou karena sebagian besar masyarakat desa berprofesi sebagai petani. Guna menjaga hasil tanam yang baik maka para petani sangat 
membutuhkan obat pertanian agar tanaman yang ditanam akan memperoleh hasil yang maksimal sesuai dengan harapan para petani.

2. Usaba percetakan batu bata. Usaha percetakan batu bata yang dilakukan BUMDes "Karivela" merupakan salah usaha yang memanfaatkan sumbersumber potensi desa yang tersedia di wilayah Desa Akedotilou. BUMDes "Karivela" yang berada di Desa Akedotilou merupakan daerah yang berada pada daratan pesisir pantai, sehingga material yang dibutuhkan untuk membuat usaha batu bata sangat mudah diperoleh. Sumber-sumber potensi desa yang dimaksudkan adalah pemanfaatan pasir pantai untuk pembuatan batu bata.
Dalam pengelolaan BUMDes "Karivela", yang merupakan suatu badan usaha untuk menjalin kerja sama yang dengan masing-masing anggota maupun pemerintah desa, tentunya ada mekanisme yang harus dilakukan dalam pengelolaan untuk melakukan kerja sama dengan satu dengan yang lain. Untuk memelihara semangat kerja maka hubungan harmonis komunikasi menjadi hal penting dalam manajemen BUMDesa (Nilawati, 2018). Dengan demikian, BUMDes "Karivela" memiliki struktur organisasi untuk menggambarkan kerja sama untuk sistem koordinasi antar masing-masing pengurus. Gambar 1 menunjukkan struktur organisasi BUMDes "Karivela".

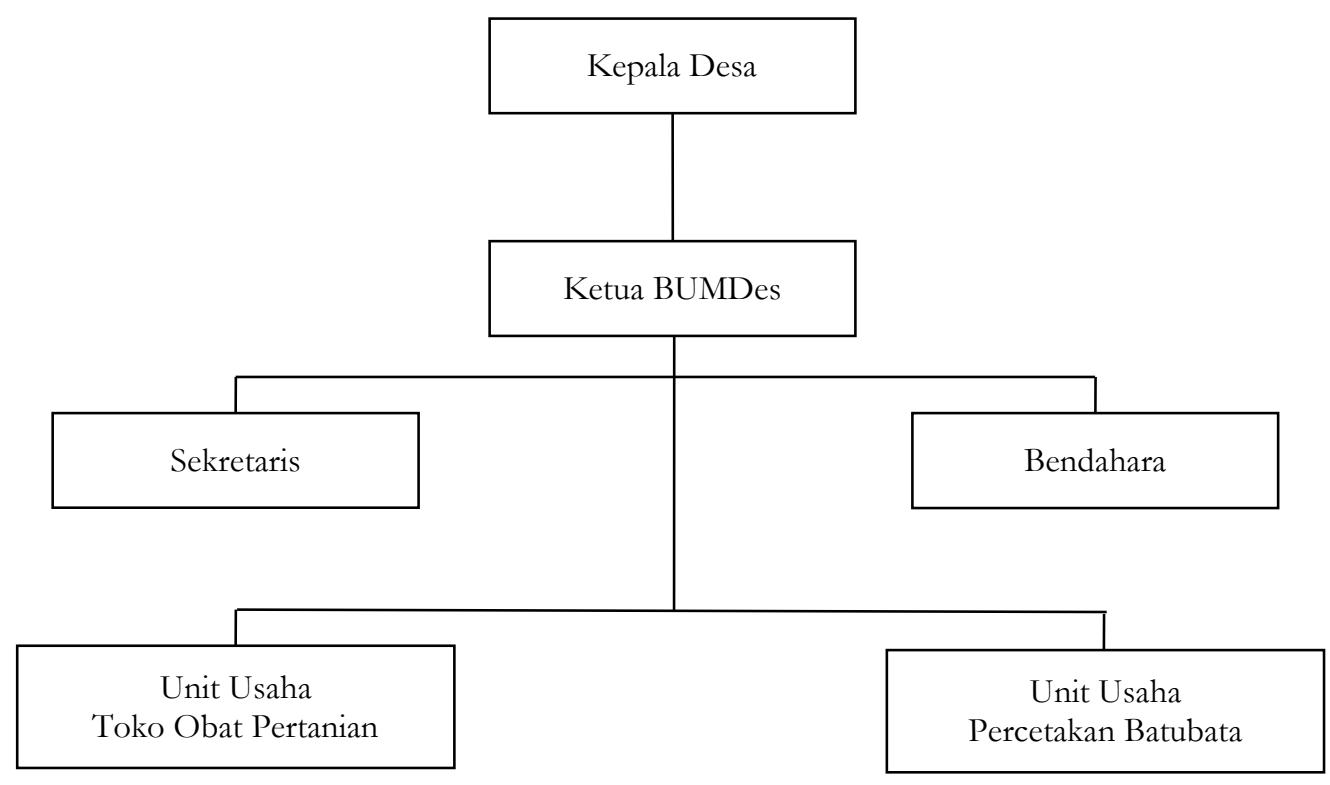

Gambar 1. Struktur Organisasi BUMDes “Karivela” Akedotilou

\section{Kinerja BUMDes "Karivela" dalam pengelolaan anggaran}

Kinerja organisasi sektor dapat dilihat dari kemampuan untuk pengelolaan anggaran, setiap anggaran yang diperoleh (BUMDes) harus dilaporkan dalam bentuk laporan keuangan yang telah ditentukan dalam satu periode waktu tertentu. Laporan keuangan mengandung pengertian sebagai salah satu proses pengumpulan, pengelolaan, dan pengkomunikasian informasi yang bermanfaat untuk pembuatan keputusan dan untuk menilai kinerja organiasasi sektor publik (Mardiasmo, 2009:159). 
Tabel 1. Alokasi Dana Desa Akedotilou

\begin{tabular}{lrrlll}
\hline \multicolumn{1}{c}{ Alokasi Dana Desa } & & Jumlah & \% & \multicolumn{2}{c}{ Alokasi BUMDes } \\
\hline Tahun 2017 & Rp & 1.940 .400 .000 & & & \\
Pencairan Tahap I & Rp & 776.160 .000 & $40 \%$ & Rp & 250.000 .000 \\
Pencairan Tahap II & Rp & 776.160 .000 & $40 \%$ & Rp & 150.000 .000 \\
Pencaiaran Tahap III & Rp & 388.080 .000 & $20 \%$ & & \\
\hline & & & Total & Rp & 400.000.000 \\
\hline
\end{tabular}

Sumber: Pemdes Akedotilou, 2020

Berdasarkan data informan pemerintah Desa Akedotilou, Tabel 1 menunjukkan bahwa pada tahun 2017 BUMDes "Karivela" mulai dibentuk, dan menerima penyertaan modal dari pemerintah desa melalui Alokasi Dana Desa. Alokasi Dana Desa (ADD) di Desa Akedotilou sebesar Rp. 1.940.400.000, yang diterima dalam 3 (tiga) tahap pencairan dari pemerintah daerah dengan besaran per masing-masing tahap sesuai dengan Peraturan Menteri Keuangan, yaitu tahap pertama $40 \%$, tahap kedua $40 \%$, dan tahap ketiga $20 \%$ dari total Alokasi Dana Desa yang telah ditetapkan per tahun. Berdasarkan persentasi yang ditetapkan maka pada tahap I, Desa Akedotilou menerima Alokasi Dana Desa sebesar Rp. 776.160.000, tahap II sebesar Rp. 776.160.000, dan pada tahap III sebesar Rp. 388.080.000. Pada pencairan tahap I, pemerintah desa mengalokasikan anggaran ke rekening kas BUMDes "Karivela" sebesar Rp. 250.000.000, dan pemerintah desa menambahkan alokasi ke rekening kas BUMDes "Karivela" sebesar Rp. 150.000.000 dari pencairan tahap II, sehingga total penyertaan modal ke BUMDes "Karivela" sebesar Rp. 400.000.000.

BUMDes dikatakan memiliki kinerja yang baik, maka harus mampu mengelola anggaran dengan sebaik-baiknya agar menghasil pendapatan yang sebesarbesarnya. Sebagai sebuah lembaga yang juga diwajibkan mendapat profit, tentunya ada mekanisme yang harus ditaati oleh pengelola BUMDes dalam melakukan kerja sama dengan pihak lain (Candraningsih et al., 2018). Pengelolaan anggaran membutuhkan pertanggungjawaban yang jelas dan transparan atas setiap penggunaan anggaran yang dikelola. Hasil penelitian ini menunjukkan bahwa BUMDes "Karivela" saat ini mengalami krisis kepercayaan baik dari pemerintah desa maupun masyarakat karena tidak adanya pertanggungjawaban pengelolaan anggaran yang dilakukan pengurus BUMDes "Karivela" ke Pemerintah Desa Akedotilou. Saat ini, BUMDes "Karivela" dinilai tidak berjalan maksimal karena cenderung disebabkan masalah internal. Dengan demikian setiap jenis usaha yang telah dilakukan tidak lagi dijalankan oleh pengurus yang bertanggungjawaban dalam pengelolaan dan menjalankan BUMDes. Hal ini dibuktikan dengan tidak adanya penyertaan modal oleh pemerintah desa sejak tahun 2018 sampai dengan tahun 2020.

Pengelolaan anggaran yang dilakukan BUMDes "Karivela" diperoleh dari penyertaan modal Pemerintah Desa Akedotilou. Pemerintah Desa Akedotilou menyampaikan bahwa pengurus BUMDes "Karivela" pada tahun 2017 telah mendapatkan alokasi anggaran yang langsung disetor ke rekening kas BUMDes "Karivela" dan sampai pada tahun 2020 pengurus BUMDes belum melakukan pertanggungjawaban anggaran secara transparan ke pemerintah desa maupun masyarakat. Hal ini menyebabkan informasi keuangan dari BUMDes "Karivela" cenderung tidak akuntabel. Informasi keuangan bertujuan memberikan informasi kepada publik serta memberikan informasi yang berguna dalam pertimbangan pengambilan keputusan tersebut serta sebagai bentuk pertanggungjawaban (Irawati dan Martanti, 2017).

Sejak tahun 2017, BUMDes "Karivela", menerima penyertaan modal dari pemerintah desa dengan total sebesar Rp. 400.000.000, dan sisa anggaran yang tercatat di rekening kas BUMDes masih sebesar Rp. 200.000.000 sehingga pada 3 (tiga) tahun 
terakhir ini pemerintah desa tidak lagi melakukan penyertaan modal ke BUMDes "Karivela". Dengan demikian, bukan berarti BUMDes "Karivela" sudah mandiri dalam mengelola anggaran dan sumber potensi desa dengan baik, akan tetapi anggaran yang disetor ke kas BUMDes "Karivela" sampai tahun 2020 belum mampu dikelola dan dimaksimal dengan baik dalam mengelola kelembagaan BUMDes dan sumber-sumber potensi yang ada di desa, agar menghasilkan pendapatan yang besar demi keberlanjutan kelembagaan BUMDes dan kesejahteraan masyarakat desa.

\section{Kinerja BUMDes "Karivela" dalam mengelola potensi desa}

Potensi desa merupakan kekayaan atas segala sesuatu yang ada di desa, yang dapat dimanfaatkan oleh pemerintah desa maupuan masyarakat demi kepentingan dan kesejahteraan masyarakat desa. Salah satu indikator untuk menilai kinerja BUMDes adalah bagaimana BUMDes dapat mengelola sumber-sumber potensi desa yang bisa dimanfaatkan untuk meningkatkan pendapatan desa melalui potensi yang ada. Keberadaan BUMDes bagi masyarakat desa adalah meningkatkan produktifitas masyarakat desa melalui unit-unit usaha dan potensi produktif ekonomi masyarakat (Bemba et al., 2019). Lebih lanjut, dalam proses penyusunan program maupun pengalokasi anggaran, BUMDes harus lebih peka terhadap masalah ini, mengakomodir kebutuhan dan potesi desa merupakan bagian dari menciptakan daya saing ekonomi berkelanjutan bagi masyarakat.

Berdasarkan informasi yang diberikan dari informan bahwa sumber-sumber potensi desa yang ada di Desa Akedotilou sangat banyak untuk dikelola oleh BUMDes untuk dijadikan sumber pendapatan BUMDes agar dapat meningkatkan kinerja BUMDes untuk mengelola dan meningkatkan pendapatan BUMDes, akan tetapi pengurus BUMDes "Karivela" belum mampu mengelola potensi desa secara maksimal dan bahkan yang sudah dikelola oleh BUMDes "Karivela" sekarang ini tidak mampu untuk merekrut karyawan baru untuk mengelola dan menjalankan setiap program kerja BUMDes. Hal ini menunjukkan bahwa pengurus BUMDes "Karivela" belum mampu mengurus kelembangaan BUMDes, baik dari segi pengelolaan sumber potensi desa maupun tata kelola keuangan BUMDes.

Dalam pengelolaan BUMDes dengan sistem manajemen dan sumber daya manusia yang mampu diandalkan maka setiap pengelolaan kelembagaan BUMDes akan berjalan maksimal sesuai dengan tujuan BUMDes. Pengelolaan BUMDes harus dikelola secara profesional dan mandiri sehingga diperlukan orang-orang yang memiliki kompetensi untuk memngelolanya (Candraningsih et al., 2018). Kinerja BUMDes "Karivela" dalam mengelola potensi desa saat dikatakan tidak maksimal karena minimnya sumber daya manusia yang mengurus badan usaha tersebut, sehingga potensi yang telah digali tidak menunjukkan peningkatan terhadap sumber pengelolaan potensi desa.

\section{Kesimpulan dan saran Kesimpulan}

Hasil penelitian ini menyimpulkan bahwa BUMDes "Karivela" di Desa Akedotilou Kecamatan Oba Tengah masih belum berjalan maksimal, apabila ditinjau dari sudut pengelolaan anggaran oleh BUMDes "Karivela" karena mempertanggungjawaban pengelolaan anggaran ke Pemerintah Desa Akedotilou Kecamatan Oba Tengah Kota Tidore Kepulauan sampai saat ini belum dilakukan oleh pengurus BUMDes "Karivela". Sehingga setiap anggaran BUMDes "Karivela" diketahui tidak memiliki transparansi, baik pengelolaan maupun pertanggungjawabannya. Sedangkan dalam pengolahan potensi desa yang ada di Desa Akedotilu Kecamatan Oba Tengah Kota Tidore Kepulauan yang dikelola BUMDes "Karivela" juga masih tidak menunjukkan peningkatan terhadap unit-unit usaha yang ada. Bahkan unit-unit usaha dibangun yang saat ini juga sudah tidak maksimal lagi dijalankan oleh pengurus BUMDes itu sendiri. 


\section{Saran}

Berdasarkan pembahasan yang telah dijelaskan diatas, maka saran penelitian ini adalah:

1. Pengurus BUMDes dapat meningkatkan pemahaman terkait dengan pengembangan tata kelola BUMdes itu sendiri untuk meningkatkan kemandirian BUMDes itu.

2. Pemerintah Desa Akedotilou agar lebih mengawasi kinerja BUMDes agar kinerja BUMDes bisa lebih menunjukkan perkembangan dalam kinerjanya lagi sehingga pengurus BUMDes benarbenar dijalankan sesuai dengan tujuan dan prinsip-prinsip BUMDes.

3. Penelitian lanjutan di bidang yang sama agar dapat menganalisis faktor lain yang mempengaruhi kinerja BUMDes dan dapat menggunakan metode lain untuk menggali informasi lebih detail lagi terkait dengan kinerja BUMDes.

\section{Ketersediaan data}

Data penelitian ini dapat diakses secara terbuka pada dokumen pendukung artikel (supplementary file).

\section{Daftar pustaka}

Agunggunanto, E. Y., Arianti, F., Kushartono, E. W., \& Darwanto. (2016). Pengembangan desa mandiri melalui pengelolaan Badan Usaha Milik Desa (BUMDes). Jurnal Dinamika Ekonomi dan Bisnis, 13(1), 67-81. https://ejournal.unisnu.ac.id/JDEB/article/vie $\underline{\mathrm{w} / 395}$

Bemba, Y., Rusniati, \& Mailensun, T. P. (2019). Faktor yang mempengaruhi pengelolaan BUMDes di Desa Rumbia Kecamatan Botumoito Kabupaten Gorontalo. Jurnal Politico, 8(1), 1-6. https://ejournal.unsrat.ac.id/index.php/politico Larticle/view/30492

Candraningsih, K. E., Sarayanti, K. Y., Pratiwi, P. R., Suryantini, L. P., Juliantari, I. G. A. D., \& Devilaksmi, A. T. (2018). Pengelolaan keuangan dan sumber daya manusia pada BUMDes Bulian Kecamatan Kubutambahan. Jurnal Ilmiah Akuntansi dan Humanika, 8(1), 24-32. http://dx.doi.org/10.23887/jinah.v8i1.19858

Hehanussa, S. J. (2015). Pengaruh penyajian laporan keuangan daerah dan aksesibilitas laporan keuangan daerah terhadap transparansi dan akuntabilitas pengelolaan keuangan daerah Kota
Ambon. Conference In Business, Accounting, And Management (CBAM), 2(1), 82-90. http://lppmunissula.com/jurnal.unissula.ac.id/index.php/cb $\mathrm{am} /$ article/view/294

Irawati, D., \& Martanti, D. E. (2017). Transparansi pengelolaan laporan keuangan bumdes terhadap pelaporan aset desa (Studi fenomenologi pada BUMDes Desa Karangbendo Kec Ponggok Kab Blitar). Seminar Nasional dan Call for Paper Ekonomi dan Bisnis (SNAPER-EBIS): Strategi Pengelolaan Sumber Daya Daerah dalam Menciptakan Good Governance, $\quad$ 1(1), 41-51. https://jurnal.unej.ac.id/index.php/prosiding/ar ticle/view/6665

Mardiasmo. (2009). Akuntansi Sektor Publik, Cetakan Keempat. Yogyakarta: CV Andi Offset.

Nugrahaningsih, P., Falikhatun, F., \& Winarna, J. (2016). Optimalisasi dana desa dengan pengembangan Badan Usaha Milik Desa (BUM Des) menuju desa mandiri. Jurnal Akuntansi dan Bisnis, 16(1), 37-45. http://dx.doi.org/10.20961/jab.v16i1.190

Nilawati, E. (2018). Analisis manajemen Badan Usaha Milik Desa (BUMDESA) "Hanyukupi" Desa Ponjong Kecamatan Ponjong Kabupaten Gunungkidul. Jurnal Wacana Kinerja, 21(1), 49-72. http://dx.doi.org/10.31845/jwk.v21i1.65

Peraturan Menteri Dalam Negeri Nomor 39 Tahun 2010 tentang Badan Usaha Milik Desa.

Permendagri Nomor 113 Tahun 2014 tentang Pengelolaan Keuangan Desa.

Risal, Wulandari, R., \& Jaurino. (2020). Pendampingan akuntansi dan keuangan BUMDes Sedahan Jaya Kecamatan Sukadana Kabupaten Kayong Utara. Cendekia: Jurnal Pengabdian Masyarakat, 2(1), 4957. https://doi.org/10.32503/cendekia.v2i1.949

Sasauw, C., Gosal, R., \& Waworundeng, W. (2018). Efektivitas Badan Usaha Milik Desa (Bumdes) dalam meningkatkan masyarakat di Desa Lenganeng Kecamatan Tabukan Utara Kabupaten Kepulauan Sangihe. Jurnal Eksekutif, 1(1), $1-10$. https://ejournal.unsrat.ac.id/index.php/jurnalek $\underline{\text { sekutif/article/view/21940 }}$

Sugiyono, 2016. Metode Penelitian Kuantitatif, Kualitatif dan R\&D. Bandung: PT Alfabet.

Sukarini, L., Dewi, P. E. D. M., \& Wahyuni, M. A. (2018). Pengaruh tingkat pendidikan, pengalaman kerja, pelatihan, dan penggunaan teknologi informasi terhadap kualitas laporan keuangan BUMDes di Kecamatan Negara. Jurnal Ilmiah Mahasiswa Akuntansi (JIMAT) Undiksha, 9(3), 85-97. https://ejournal.undiksha.ac.id/index.php/S1ak Larticle/view/20429

Swandari, N. K. A. S., Setiawina, N. D., \& Marhaeni, A. A. I. N. (2017). Analisis faktor-faktor penentu kinerja karyawan BUMDes di Kabupaten Jembrana. E-Jurnal Ekonomi dan Bisnis Universitas Udayana, 06(04), 1365-1394. https://ojs.unud.ac.id/index.php/EEB/article/v iew $/ 24184$

Undang-Undang Nomor 32 Tahun 2004 tentang Pemerintahan Daerah. 